\title{
Taste receptors type 2 would not mediate bitter tastant-induced relaxation of airway smooth muscle
}

\begin{abstract}
Recently, it has been found that taste receptors type 2 (TAS2R) are expressed in airway smooth muscle (ASM) cells and their activators bitter tastants inhibit ASM contraction induced by agonists. In this mini review, we summarized the progress in understanding of bitter Tastant-induced ASM relaxation. We also mentioned the inhibitory action and the underlying mechanism of bitter tastants extracted from bitter herbs. These recent findings indicate that bitter tastants would be a novel class of bronchodilators for the treatment of obstructive lung diseases such as asthma and chronic obstructive pulmonary disease (COPD).
\end{abstract}

Volume 7 Issue I - 2017

\author{
Qing-Hua Liu \\ College of Life Sciences, China
}

Correspondence: Qing-Hua Liu, Institute for Medical Biology \& Hubei Provincial Key Laboratory for Protection and Application of Special Plants in Wuling Area of China, College of Life Sciences, South-Central University for Nationalities, Wuhan 430074, China, Email ilu258q@yahoo.com

Received: February 12, 2017| Published: May II, 2017

\section{Mechanism of bitter tastant-induced relaxation}

Taste receptors type 2 (TAS2R) are responsible for detecting bitter sensation, ${ }^{1}$ which have recently been found to be expressed in ASM cells and which mediate inhibition on the pre contraction through large-conductance $\mathrm{Ca}^{2+}$-activated $\mathrm{K}^{+}$channels $(\mathrm{BKs})^{2,3}$ However, our and others' results indicate that the relaxation would not be mediated by BKs, which will result from the inhibition of L-type voltage-dependent $\mathrm{Ca}^{2+}$ channels (LVDCCs) and non-selective cat ion channels (NSCCs). ${ }^{4-7}$ These studies clarified the paradox about the mechanism of bitter Tastant-induced relaxation. Bitter tastants induce $\mathrm{Ca}^{2+}$ store release leading to cytosolic $\mathrm{Ca}^{2+}$ increases through the TAS2R-G $\mathrm{G}_{\beta \gamma}$ protein-PLC $\beta-\mathrm{IP}_{3}-\mathrm{IP}_{3} \mathrm{R}$ pathway, however, the increased $\mathrm{Ca}^{2+}$ does not cause a contraction. ${ }^{5,8}$ This would be because that the increase of $\mathrm{Ca}^{2+}$ did not reach the threshold level of triggering a contraction, which might be due to that bitter tastants inhibited $\mathrm{Ca}^{2+}$ release channels such as ryanodine receptors (RyRs) and $\mathrm{IP}_{3}$ receptors $\left(\mathrm{IP}_{3} \mathrm{Rs}\right)$, since that bitter tastants blocked caffeine (an activator of RyRs)-induced cytosolic $\mathrm{Ca}^{2+}$ increases ${ }^{7}$ and ACHinduced $\mathrm{Ca}^{2+}$ oscillations mediated by $\mathrm{IP}_{3} \mathrm{R}$-induced $\mathrm{Ca}^{2+}$ release. ${ }^{9,10}$ Thereby, bitter Tastant-induced $\mathrm{Ca}^{2+}$ release would be inhibited, leading to that the cytosolic $\mathrm{Ca}^{2+}$ cannot increase to the level for evoking a contraction.

However, the agonist $\mathrm{ACH}$-induced the $\mathrm{Ca}^{2+}$ release from the intracellular store mediated by $\mathrm{IP}_{3} \mathrm{Rs}$ will not be inhibited, thereby, which leads to a depletion of the store to activate SOC (store-operated channels) such as the NSCCs. ${ }^{6}$ In addition, ACH (or methacholine) also activates LVDCCs. ${ }^{5,6}$ This $\mathrm{Ca}^{2+}$ per meant ion channels will then mediate $\mathrm{Ca}^{2+}$ influx, resulting in a sustained contraction. If these channels were blocked by bitter tastants, the pre contraction will then be inhibited. ${ }^{5,6}$

Overall, bitter tastants induce $\mathrm{Ca}^{2+}$ increases through activating intracellular ion channels by the TAS2R-mediated signal pathway, however, the channels are then directly inhibited by bitter tastants, thereby, the $\mathrm{Ca}^{2+}$ elevations are observed and the resultant contraction is not noted. Except for inhibiting these intracellular ion channels, bitter tastants can also inhibit the plasma ion channels activated by the $\mathrm{Ca}^{2+}$ store depletion, which then leads to a reduction of intracellular $\mathrm{Ca}^{2+}$ and eventually induces a relaxation. Thus, this relaxation induced by bitter tastants would not be mediated by the TAS2Rs.

\section{Bitter tastants as new bronchodilators}

Above results indicate that bitter tastants would be potent bronchodilators, which can be used to treat obstructive lung diseases such as asthma and COPD, ${ }^{11-16}$ particularly based on that bitter tastants inhibit the pre contraction of human ASM. ${ }^{14,15}$ However, the inhibitory action of bitter tastants to ASM contraction might not be through the TAS2Rs on the basis of the above descriptions.

\section{Relaxant action of herbal bitter tastants}

We recently further extracted compounds from bitter herbs Plumula Nelumbinis ${ }^{17}$ and Cortex phellodendri ${ }^{18}$ and investigated their effects on ASM contraction. The extracts, which tasted bitter, inhibited ACH-induced pre contraction of mouse ASM by inhibiting LVDCCs and NSCCs, similar to that of the known bitter tastants used in the studies described above. Moreover, such relaxation was observed in tracheal and bronchial ASM from controls and mouse models of asthma, suggesting this bitter tastants-induced relaxation will be regardless of ASM locations and diseased ASM. Our results also indicate that, except for these two types of channels, there will be another pathway that mediates these extracted bitter tastants-induced relaxations. Since that following blockade of these channels, the remaining pre contraction was observed and then completely blocked by the extracts. The unknown pathway remains to be further defined. These findings suggest that bitter tastants from bitter herbs could also be used to develop new bronchodilators.

\section{Conclusion}

Bitter tastants induce intracellular $\mathrm{Ca}^{2+}$ increases through the TAS2R-G $\mathrm{G}_{\beta \gamma}$ protein-PLC $\beta-\mathrm{IP}_{3}-\mathrm{IP}_{3} \mathrm{R}$ pathway, however, which also inhibit $\mathrm{IP}_{3} \mathrm{R}$. Thereby, the $\mathrm{Ca}^{2+}$ increase would not be large enough to trigger a contraction. In addition, bitter tastants can inhibit plasma $\mathrm{Ca}^{2+}$ per meant ion channels activated by agonists, leading to the contraction to be inhibited, in which the TAS2Rs are not involved.

\section{Acknowledgments}

None.

\section{Conflicts of interest}

Author declares there are no conflicts of interest. 


\section{Funding}

None.

\section{References}

1. Prandi S, Bromke M, Hubner S, et al. A subset of mouse colonic goblet cells expresses the bitter taste receptor Tas2r131. PLoS One. 2013;8(12):e82820

2. Deshpande DA, Wang WC, McIlmoyle EL, et al. Bitter taste receptors on airway smooth muscle bronchodilate by localized calcium signaling and reverse obstruction. Nat Med. 2010;16(11):1299-1304.

3. An SS, Robinett KS, Deshpande DA, et al. Reply to: Activation of BK channels may not be required for bitter Tastant-induced bronchodilation. Nat Med. 2012;18(5):650-651.

4. Zhang CH, Chen C, Lifshitz LM, et al. Activation of BK channels may not be required for bitter Tastant-induced bronchodilation. Nat Med. 2012;18(5):648-650.

5. Zhang CH, Lifshitz LM, Uy KF, et al. The cellular and molecular basis of bitter Tastant-induced bronchodilation. PLoS Biol. 2013;11(3):e1001501.

6. Zhang T, Luo XJ, Sai WB, et al. Non-selective cation channels mediate chloroquine-induced relaxation in pre-contracted mouse airway smooth muscle. PLoS One. 2014;9(7):e101578.

7. Wei MY, Xue L, Tan L, et al. Involvement of large-conductance $\mathrm{Ca}^{2+}$ activated $\mathrm{K}^{+}$channels in chloroquine-induced force alterations in precontracted airway smooth muscle. PLoS One. 2015;10(3):e0121566.

8. Camoretti-Mercado B, Pauer SH, Yong HM, et al. Pleiotropic Effects of Bitter Taste Receptors on $\left[\mathrm{Ca}^{2+}\right]$ i Mobilization, Hyper polarization, and Relaxation of Human Airway Smooth Muscle Cells. PLoS One. 2015;10(6):e0131582.
9. Bai Y and Sanderson MJ. Airway smooth muscle relaxation results from a reduction in the frequency of $\mathrm{Ca}^{2+}$ oscillations induced by a cAMPmediated inhibition of the $\mathrm{IP}_{3}$ receptor. Respir Res. 2006;7(1):34.

10. Bai Y, Krishnamoorthy N, Patel KR, et al. Cryopreserved Human Precision-Cut Lung Slices as a Bioassay for Live Tissue Banking. A Viability Study of Bronchodilation with Bitter-Taste Receptor Agonists. Am J Respir Cell Mol Biol. 2016;54(5):656-663.

11. Sanderson MJ, Madison JM. Bitter treats for better breathing. Nat Med 2010;16(11):1190-1191.

12. Tse MT. G protein-coupled receptors: Breathing easier with bitter tastes. Nat Rev Drug Discov. 2010;9(12):918-919.

13. Zhu MS. A "bitter" end to asthma revealed. Protein Cell. 2011;2(6):433-434.

14. Morice AH, Bennett RT, Chaudhry MA, et al.Effect of bitter tastants on human bronchi. Nat Med. 2011;17(7):775.

15. Belvisi MG, Dale N, Birrell MA et al.Bronchodilator activity of bitter tastants in human tissue. Nat Med. 2011;17(7):776.

16. Robinett KS, Koziol-White CJ, Akoluk A, et al. Bitter taste receptor function in asthmatic and non asthmatic human airway smooth muscle cells. Am J Respir Cell Mol Biol. 2014;50(4):678-683.

17. Tan L, Chen W, Wei MY, et al. Relaxant action of plumula nelumbinis extract on mouse airway smooth muscle. Evid Based Complement Alternat Med. 2015;2015:523640.

18. Jiang QJ, Chen W, Dan H, et al. Cortex phellodendri Extract Relaxes Airway Smooth Muscle. Evid Based Complement Alternat Med. 2016;2016:8703239. 